\title{
Endoscopic Removal of Two Esophageal Over-The-Scope Clips with Cold Saline Solution Technique
}

\author{
Marta Rocha ${ }^{a}$ Ricardo Küttner Magalhães ${ }^{a}$ Luís Maia $^{a}$ Teresa Moreira ${ }^{a}$ \\ Sílvia Barrias ${ }^{a} \quad$ Carlos Nogueira $^{b} \quad$ Isabel Pedroto ${ }^{a}$ \\ a Department of Gastroenterology, Hospital de Santo António/Centro Hospitalar do Porto, Porto, Portugal; \\ ${ }^{b}$ Department of Surgery, Hospital de Santo António/Centro Hospitalar do Porto, Porto, Portugal
}

\section{Keywords}

Endoscopic clip removal · Endoscopy · Fistula ·

Over-the-scope clip

\section{Remoção Endoscópica Esofágica de Dois Over-the-Scope Clips Pela Técnica de Soro Frio}

\section{Palavras Chave}

Remoção endoscópica de clips · Endoscopia · Fístula •

Over-the-scope clip

A 51-year-old man with a T4N1M0 gastric adenocarcinoma underwent neoadjuvant chemotherapy and total gastrectomy with Roux-en-Y esophagojejunostomy. Due to clinical worsening in the immediate postoperative period, an abdominal computed tomography was performed, revealing an empyema and a fistulous tract between the distal esophagus and the pleural cavity. The patient was initially treated with broad spectrum antibiotics and total parenteral nutrition, without clinical improvement. Endoscopy was then performed with identification of the esophageal orifice of the fistula and it was decided to proceed to endoscopic closure of the fistula with an over-the-scope clip (OTSC). Destruction of the epithelial lining of the accessible part of the fistulous tract

\section{KARGER}

E-Mail karger@karger.com www.karger.com/pjg
(C) 2018 Sociedade Portuguesa de Gastrenterologia Published by S. Karger AG, Basel

Karger

Open access

This article is licensed under the Creative Commons AttributionNonCommercial-NoDerivatives 4.0 International License (CC BYNC-ND) (http://www.karger.com/Services/OpenAccessLicense) Usage and distribution for commercial purposes as well as any distribution of modified material requires written permission. with argon plasma coagulation was conducted followed by the application of an OTSC. A second OTSC was placed to ensure complete closure of the fistula. Reassessment with gastrografin transit showed no leakage of contrast. The patient resumed oral feeding with good tolerance and was discharged 10 days after the endoscopic procedure without any complications. Six weeks later he presented with dysphagia, regurgitation, and weight loss. Endoscopy documented the presence of the 2 OTSC attached to each other and partially migrated to the lumen, causing luminal obstruction at the level of the esophagojejunal anastomosis. After an unsuccessful attempt to remove them with a conventional foreign-body grasper (Fig. 1), a second attempt was performed by submerging the clips for $1 \mathrm{~min}$ with cold saline solution previously kept in the refrigerator (Fig. 2; online suppl. Video 1, see www.karger.com/doi/10.1159/000487152), and with successive twisting maneuvers of the corners of the OTSC with a grasper it was possible to remove them "en bloc" with little resistance (Fig. 3). Thereafter, the patient repeated a gastrografin transit with adequate contrast progression and was discharged uneventfully.

The OTSC, commonly known as the "bear claw," can provide full-thickness closure of open defects up to 2-3 $\mathrm{cm}$ with greater compressive force than through-thescope clips. Consequently, OTSC have the ability to close 


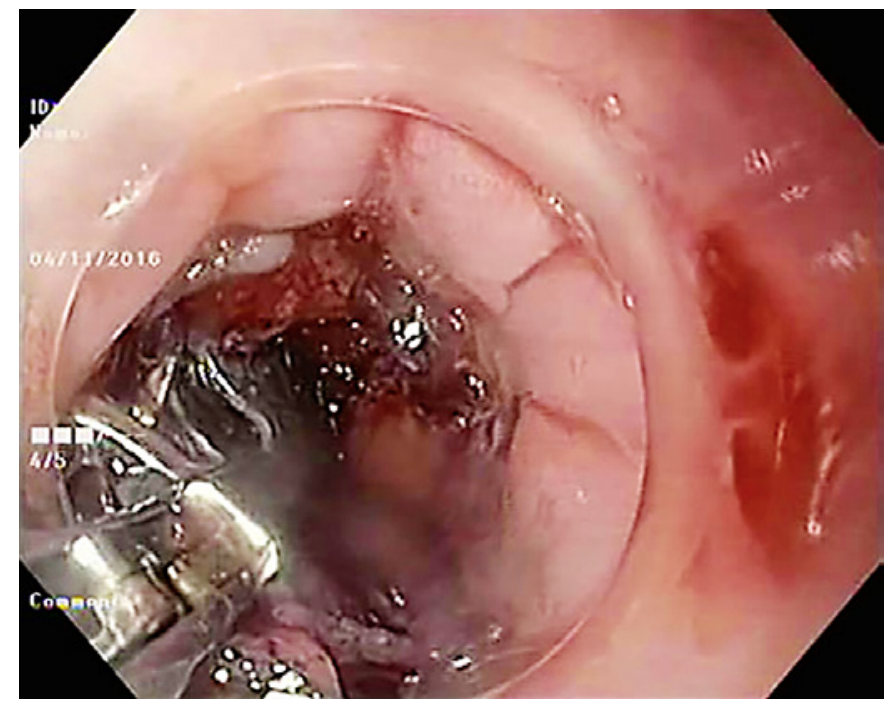

Fig. 1. Removal attempt of luminal obstructing OTSC with a conventional foreign-body grasper.

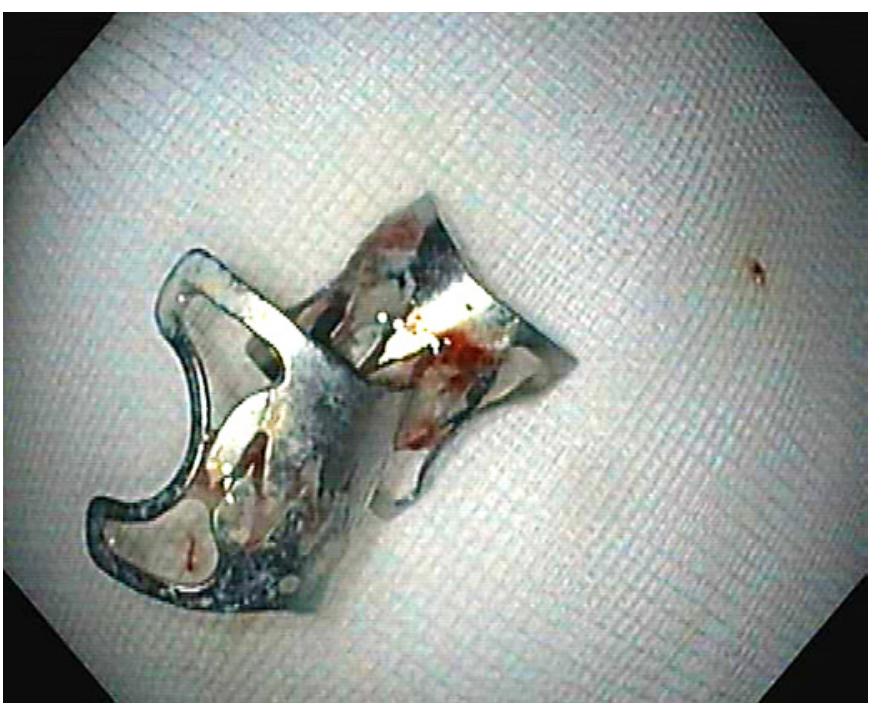

Fig. 3. Conglomerate of 2 OTSC after removal.

long-lasting leaks and fistulas even when the tissue surrounding the defect is inflamed or indurated [1]. While OTSC are able to stay in place for long periods of time, they may need to be removed under certain circumstances, as in the case of misplacement or after healing of the defect. Thus, the availability of techniques to do so is important. In the presented case, the difficulty of removal was increased by the presence of 2 OTSC attached to each other forming a conglomerate that was adherent to the mucosa. Interestingly, these clips are made of the alloy

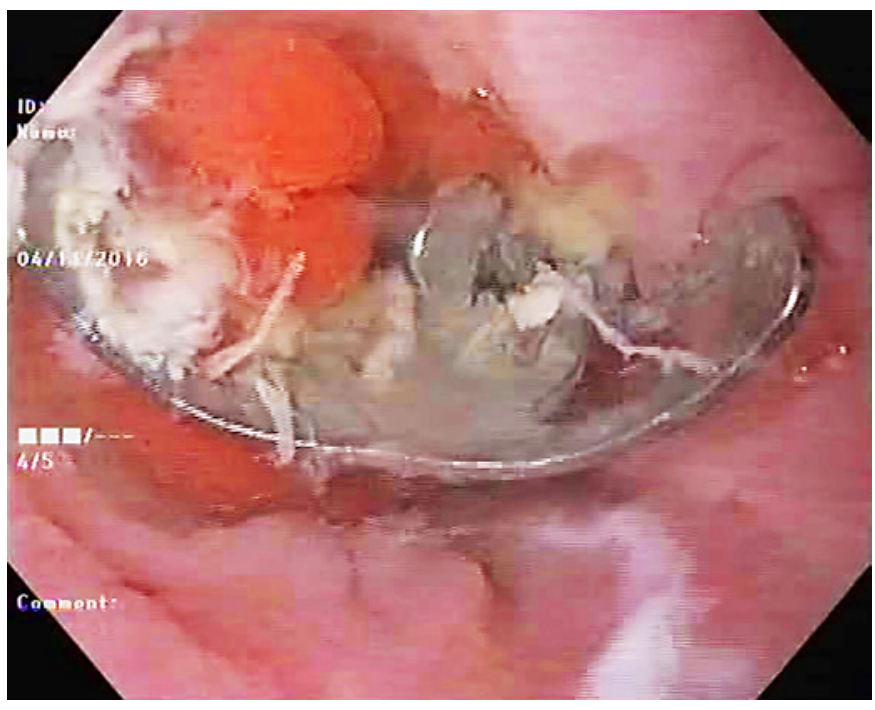

Fig. 2. OTSC submerged in cold saline solution.

nitinol, which allows them to change stiffness based on temperature. At temperatures below $10^{\circ} \mathrm{C}$, the material changes to its martensitic grid structure, becoming malleable and being easily capable of changing shape while applying reduced force. Once heated, the OTSC return to their original shape, generating high force $[2,3]$. Thanks to this feature, the clips were removed safely.

\section{Statement of Ethics}

This study did not require informed consent or review/approval by the appropriate ethics committee.

\section{Disclosure Statement}

The authors have no conflicts of interest to declare.

References

1 Rogalski P, Daniluk J, Baniukiewicz A, Wroblewski E, Dabrowski A: Endoscopic management of gastrointestinal perforations, leaks and fistulas. World J Gastroenterol 2015;21: 10542-10552.

2 Krishna SG, Shakhatreh M: Endoscopic removal of over-the-scope clip with cold saline solution technique. Gastrointest Endosc 2016;84:850-851.

3 Arezzo A, Bullano A, Fischer H, Morino M: The way to remove an over-the-scope-clip (with video). Gastrointest Endosc 2013;77: 974-975. 